\title{
PERLINDUNGAN HUKUM TERHADAP PEMILIK HAK ATAS SATUAN RUMAH SUSUN TANPA SERTIPIKAT (STUDI KASUS APARTEMEN CASA GRANDE RESIDENCE)
}

\section{LEGAL PROTECTION FOR THE OWNER OF THE RIGHT TO APARTMENT UNITS WITHOUT A CERTIFICATE (CASE STUDY OF THE CASA GRANDE RESIDENCE APARTMENT)}

\author{
Zana Zerlina, Taupiqqurrahman \\ Fakultas Hukum, Universitas Pembangunan Nasional Veteran Jakarta \\ Jl. RS Fatmawati Nomor 1, Pondok Labu, Jakarta Selatan \\ Email: zanazerlina@upnvj.ac.id
}

\begin{abstract}
Abstrak
PT. Elite Prima Hutama adalah pengembang Apartemen Casa Grande Residence. Antara PT. Elite Prima Hutama dengan Alia Febyani telah menandatangani Perjanjian Pengikatan Jual Beli (PPJB) Unit Apartemen Casa Grande Residence. Namun sejak Serah Terima Apartemen hingga saat ini belum dilaksanakan penandatanganan Akta Jual Beli sehingga tidak ada kepastian kapan akan mendapatkan Sertipikat. Tujuan dari penelitian ini adalah untuk mengetahui perlindungan hukum terhadap pemilik unit rumah susun tanpa sertipikat dan untuk mengetahui proses pengalihan hak milik kepada unit rumah susun tanpa sertipikat. Metode penelitian yang digunakan dalam artikel ini adalah yuridis-normatif dengan menelaah data sekunder. Hasil penelitian menyimpulkan bahwa sehubungan dengan perbuatan melawan hukum pengembang yang tidak menerbitkan Sertipikat, adapun perlindungan hukum terhadap pemilik satuan rumah susun adalah BW, Undang-Undang Nomor 20 Tahun 2011 tentang Rumah Susun dan UndangUndang Nomor 8 Tahun 1999 tentang Perlindungan Konsumen. Adapun proses peralihan jual beli satuan rumah susun tanpa Sertipikat yang hanya dilakukan penandatanganan PPJB yang bersifat mengikat sementara adalah tidak sah karena sebagai tanda bukti kepemilikan atas sarusun adalah diterbitkannya Sertipikat Hak Milik atas Satuan Rumah Susun.
\end{abstract}

Kata Kunci: Perlindungan hukum, Pemilik hak atas satuan rumah susun, Tanpa sertipikat.

\section{Abstract}

PT. Elite Prima Hutama, the developer of the Casa Grande Residence Apartment, has signed a Sale and Purchase Agreement with Alia Febyani for an apartment unit. However, the Sale and Purchase Deed has not been signed, so there is no certificate. This study aims to determine legal protections and to find out the process of transferring property rights to an apartment unit without a certificate. This paper uses juridical-normative research by examining secondary materials. Results of the research conclude, regarding the certificate that has not been issued due to the developer's illegal acts, the legal protection for the apartment unit owner is Indonesian Civil Code, Law Number 20 of 2011 concerning Flats and Law Number 8 of 1999 concerning Consumer Protection. As for the transfer process of buying and selling apartment units without a certificate, which is only carried out by the signing of a temporary binding PPJB, it is not valid because as proof of ownership of a synergy is the issuance of a certificate of ownership rights over the apartment unit.

Keywords: Legal protection, Owner of rights to apartment units, Without a certificate. 


\section{A. PENDAhULUAN}

Indonesia adalah negara berpenduduk padat. Sejak berdirinya pemerintahan Republik Indonesia, pemerintah bertekad untuk mensejahterakan rakyat, terutama dalam memenuhi kebutuhan rakyatnya. Kehidupan masyarakat membutuhkan berbagai barang dan jasa untuk memenuhi kebutuhannya. Kebutuhan manusia ada 3 macam, yaitu kebutuhan primer, kebutuhan sekunder dan kebutuhan tersier. Kebutuhan masyarakat yang sangat dibutuhkan dalam kehidupan adalah kebutuhan sandang, pangan, papan atau yang sering disebut dengan kebutuhan dasar. Papan merupakan salah satu kebutuhan dasar manusia yang terpenting yaitu tempat tinggal. Setiap orang membutuhkan tempat tinggal, ini merupakan kebutuhan dasar yang harus dihadapi, oleh karena itu tanah sebagai tempat tinggal manusia merupakan kebutuhan yang esensial bagi kehidupan. ${ }^{1}$

Sebagai alternatif, perumahan dan permukiman dapat mengurangi penggunaan lahan dan membuat ruang terbuka menjadi lebih luas. ${ }^{2}$ Menurut Pasal 28H (1) Undang-Undang Dasar Negara Republik Indonesia Tahun 1945, "Setiap orang berhak hidup sejahtera lahir dan batin, bertempat tinggal, dan mendapat lingkungan hidup yang baik dan sehat serta berhak memperoleh layanan kesehatan". Pemerintah harus menghormati, melindungi memelihara kebutuhan ini. ${ }^{3}$ Selain itu, Pasal 40 Undang-Undang Hak Asasi Manusia Nomor 39 tahun 1999 mengatur lebih lanjut masalah ini, yang menyatakan: "Setiap orang berhak untuk bertempat tinggal serta berkehidupan yang layak".

Pembangunan perumahan bertujuan untuk memastikan bahwa setiap keluarga memiliki rumah yang layak di lingkungan yang sehat, aman, harmonis dan teratur. ${ }^{4}$ Artinya, memiliki lingkungan yang baik dan sehat merupakan hak dasar setiap warga negara Indonesia. Sebagaimana tercantum dalam Pasal 1 angka 1 Undang-Undang Perumahan dan Permukiman Nomor 1 Tahun 2011: "Perumahan dan kawasan permukiman adalah satu kesatuan sistem yang terdiri atas pembinaan, penyelenggaraan perumahan, penyelenggaraan kawasan permukiman, pemeliharaan dan perbaikan, pencegahan dan peningkatan kualitas terhadap perumahan dan permukiman kumuh, penyediaan tanah, pendanaan dan sistem pembiayaan, serta peran masyarakat". Menyadari hal tersebut, maka perlu diusulkan suatu konsep pembangunan

\footnotetext{
${ }^{1}$ Suhanan Yosua. (2010). Hak Atas Tanah Timbul (Aanslibbing) Dalam Sistem Hukum Pertanahan Nasional. Jakarta: Restu Agung. hlm. 1.

${ }^{2}$ Urip Santoso. (2010). Pendaftaran dan Peralihan Hak Atas Tanah. Jakarta: Kencana Prenada Media. hlm. 77.

${ }^{3}$ Rosmidi, Mimi dan Imam Koeswahyono. (2010). Konsepsi Hak Milik atas Satuan Rumah Susun dalam Hukum Agraria. Malang: Setara Press. hlm. 12.

${ }^{4}$ Fauzi, Galih Husain., Ermanto Fahamsyah. (2018). Perlindungan Terhadap Konsumen Yang Tidak Mendapatkan Sertipikat Hak Milik Satuan Rumah Susun. Jurnal Hukum Adigama: Volume 1 Nomor 2. doi: http://dx.doi.org/10.24912/adigama.v1i2.2845
} 
perumahan yang dapat dibagi dalam satu bangunan bertingkat yang dibagi menjadi beberapa bagian vertikal atau horizontal yang berbeda untuk setiap penghuninya. ${ }^{5}$

Pembangunan rumah susun bertujuan untuk memenuhi kebutuhan masyarakat akan hunian yang layak dengan meningkatkan efisiensi dan hasil lahan di kawasan padat penduduk. Pengertian rumah susun bermacam-macam, rumah susun disebut juga Flat/Apartemen/Condominium. Di Indonesia, berbagai istilah yang digunakan seperti rumah susun, strata title, apartemen, flat, condominium, namun dalam undang-undang tetap disebut rumah susun karena mengacu pada Undang- Undang Nomor 20 Tahun 2011 Tentang Rumah Susun. ${ }^{6}$ Menurut Pasal 1 ayat 1 Undang-Undang Rumah Susun, disebutkan bahwa "Rumah Susun adalah bangunan Gedung bertingkat yang dibangun dalam suatu lingkungan yang terbagi dalam bagian-bagian yang distrukturkan secara fungsional, baik dalam arah horizontal maupun vertikal dan merupakan satuan-satuan yang masing-masing dapat dimiliki dan digunakan secara terpisah, terutama untuk tempat hunian yang dilengkapi dengan bagian bersama, benda bersama dan tanah bersama". ${ }^{7}$ Penguasaan atas rumah susun dapat dilakukan dengan berbagai cara, yaitu melalui pembelian atau sewa-menyewa. Saat ini perusahaan pembangunan dan permukiman menyediakan berbagai fasilitas untuk dapat memiliki rumah susun, baik yang dapat dibeli secara tunai maupun dengan mencicil. ${ }^{8}$

PT. Elite Prima Hutama adalah pengembang Apartemen Casa Grande Residence yang terletak di Jalan Casablanca Raya Kav. 88, Menteng Dalam, Tebet, Jakarta Selatan. Antara PT. Elite Prima Hutama dengan Alia Febyani telah menandatangani Perjanjian Pengikatan Jual Beli (PPJB) atas 2 (dua) Unit Apartemen Casa Grande Residence. Pembelian Unit Apartemen Casa Grande Residence dilakukan dengan menggunakan fasilitas kredit yang diterbitkan PT. BANK CIMB NIAGA. Pada tanggal 27 September 2012, pengembang telah mengirim surat kepada PT. BANK CIMB NIAGA yang menjelaskan bahwa pengembang akan menerbitkan Sertipikat Hak Milik atas Satuan Rumah Susun (SHMSRS) selambat-lambatnya 36 bulan sejak serah terima. Namun, hingga saat ini, sejak awal pembelian apartemen di tahun 2012, penghuni belum pernah mendapat pemberitahuan dari pengembang untuk menandatangani Akta Jual Beli sehingga tidak ada kepastian kapan akan mendapatkan SHMSRS. Dengan tidak adanya SHMSRS menimbulkan

\footnotetext{
${ }^{5}$ Sarri, Putri N. (2016). Hak Kepemilikan Atas Satuan Rumah Susun Yang Berstatus Hak Guna Bangunan Diatas Hak Pengelolaan (Studi Kasus Putusan No.205/Pdt.G/2007/PN.JKT.PST). Jakarta: Universitas Esa Unggul.

${ }^{6}$ Hartanto, J. Andy. (2013). Kepemilikan Hak Milik Atas Satuan Rumah Susun. Jurnal Rechtens, Volume 2, Nomorl.

${ }^{7}$ Undang-Undang Nomor 20 Tahun 2011 tentang Rumah Susun. Pasal 1 angka 1.

${ }^{8}$ Oktavia, Mulyani. (2018). Analisis Yuridis Perlindungan Konsumen Atas Kepemilikan Satuan Rumah Susun Yang Berdasarkan Akta Perjanjian Pengikatan Jual Beli (PPJB) Yang Dibangun Diatas Tanah Hak Pengelolaan (Studi Kasus Apartemen Green Pramuka City). Bekasi: Universitas Presiden. hlm 5.
} 
kerugian kepada penghuni. Dimana penghuni sangat sulit untuk menjual atau mengalihkan unit Apartemen yang dibeli.

Menurut Pasal 616 BW, pengalihan benda tidak bergerak (Apartemen) dilakukan melalui pengumuman akta yang relevan dengan cara yang ditentukan dalam Pasal $620 \mathrm{BW}$, terutama dengan mencatatnya dalam buku register. Dengan berlakunya Undang-Undang Nomor 5 Tahun 1960 (Tentang Pokok-pokok Pokok Pertanian (UUPA)), pendaftaran hak atas tanah dan kepemilikan unit rumah susun, dan pengalihan hak dilakukan sesuai dengan Pasal 19 UUPA dan pelaksanaannya. Bukti kepemilikan hak atas tanah maupun hak milik atas Satuan Rumah Susun dibuktikan dengan adanya sertipikat tanah yang dalam hal ini berupa Serifikat Hak Milik Satuan Rumah Susun (SHMSRS). ${ }^{9}$

Namun pada kenyataannya pengembang telah melakukan perbuatan melawan hukum, sebab berdasarkan Pasal 47 ayat (1) Undang-Undang Rumah Susun, "sebagai tanda bukti kepemilikan atas sarusun diatas tanah hak milik, hak guna bangunan, atau hak pakai di atas tanah negara, hak guna bangunan atau hak pakai di atas tanah hak pengelolaan diterbitkan Sertipikat Hak Milik atas Satuan Rumah Susun”. Akibat tidak diterbitkannya Sertipikat, penghuni mengalami kerugian berupa materiil yang secara nyata terjadi pada saat proses pengalihan unit Apartemen memiliki risiko dan kerentanan hukum yang lebih tinggi. ${ }^{10}$ Maupun kerugian immateriil secara beban psikologis akibat terperdaya oleh iklan dan/atau promosi investasi apartemen yang menguntungkan. Bertumpu pada latar belakang masalah tersebut, permasalahan penelitian dapat dirumuskan tentang bagaimana perlindungan hukum terhadap pemilik hak atas satuan rumah susun tanpa sertipikat dan bagaimana proses peralihan hak milik atas satuan rumah susun tanpa sertipikat.

\section{B. METODE PENELITIAN}

Jenis penelitian yang digunakan dalam penelitian ini adalah penelitian hukum normatif (yuridis normatif); Dalam penelitian ini digunakan pendekatan Undang-Undang (statue approach) dan pendekatan kasus (Case Approach). Sumber data yang digunakan penulis dalam hukum normatif adalah data sekunder, yang terdiri dari 3 (tiga) sumber bahan hukum. Pertama, bahan hukum primer terdiri dari Burgelijk Wetboek (BW); Undang-Undang No. 5 Tahun 1960

\footnotetext{
${ }^{9}$ Intan, Siti Nurul., Wardani Rizkianti. (2020). Jual Beli Apartemen Kepada Pihak Ketiga Atas Dasar Perjanjian Pengikatan Jual Beli (PPJB). Adil: Jurnal Hukum, Volume 11 Nomor 1. doi: https://doi.org/10.33476/ajl.v11i1.1445 10 Murni, Christiana Sri. (2018). Peralihan Hak Atas Tanah Tanpa Sertipikat. Lex Librum: Jurnal Ilmu Hukum, Volume 4, Nomor 2.
} 
tentang UUPA; Undang-Undang Nomor 8 Tahun 1999 tentang Perlindungan Konsumen; Undang-Undang Nomor 1 Tahun 2011 tentang Perumahan dan Kawasan Pemukiman; UndangUndang Nomor 20 Tahun 2011 tentang Rumah Susun; Peraturan Pemerintah Nomor 4 Tahun 1988 tentang Rumah Susun. Kedua, bahan hukum sekunder yang merupakan bahan hukum yang menunjang bahan hukum primer yang diperoleh dari hasil penelitian perpustakaan, yaitu semua publikasi tidak resmi yang berkaitan dengan hukum. ${ }^{11}$ Antara lain: buku-buku hukum, jurnal terkait dan skripsi yang dijadikan refrensi terkait dengan penelitian ini. Ketiga, bahan hukum tersier yang merupakan bahan yang memberikan pedoman dan penjelasan bagi bahan hukum primer dan sekunder. Seperti: kamus, ensiklopedia, indeks kumulatif, dll.

Metode pengumpulan bahan hukum yang digunakan dalam penelitian ini adalah studi peraturan perundang-undangan dan studi kasus. Analisis bahan hukum yang digunakan dalam penelitian ini bersifat deskriptif dan normatif, yaitu suatu cara untuk memperoleh gambaran singkat tentang suatu masalah. Metode ini tidak didasarkan pada informasi statistik, tetapi pada norma dan prinsip hukum terkini. Dalam analisis bahan hukum, langkah pertama yang dilakukan adalah menelusuri semua hasil penelitian yang diperoleh dari bahan hukum. Selain itu juga membahas melalui penyusunan konsep, azas / prinsip dan ketentuan hukum terkait pengaturan perjanjian yang dilarang. Berdasarkan penelitian dan penafsiran peraturan perundang-undangan, penulis menggunakan penalaran induktif untuk menghasilkan konsep-konsep yang meliputi definisi, uraian, maupun klasifikasi.

\section{PEMBAHASAN}

\section{PERLINDUNGAN HUKUM TERHADAP PEMILIK HAK ATAS SATUAN RUMAH SUSUN TANPA SERTIPIKAT}

Kepemilikan atas satuan rumah susun dikenal dengan konsep kepemilikan Strata Title. Strata Title merupakan Hak Milik Atas Satuan Rumah Susun, sebagai pemegang hak, seseorang juga berhak atas sebagian (proporsi) bagian bersama, benda bersama maupun tanah bersama. Hak atas bagian bersama, benda bersama maupun tanah bersama tidak kepada bagian atau lokasi tertentu, tetapi dalam bentuk proporsi atau presentase kepemilikan. ${ }^{12}$ Dengan Strata Title yang terdaftar dalam bentuk Sertipikat Hak Milik atas Satuan Rumah Susun tentu pemiliknya dapat memanfaatkan untuk keperluan lain.

\footnotetext{
${ }^{11}$ Zainudin Ali. (2009). Metode Penelitian Hukum. Jakarta: Sinar Grafika. hlm. 54.

${ }^{12}$ Adrian Sutedi. (2010). Hukum Rumah Susun \& Apartemen, Cet. Pertama. Jakarta: Sinar Grafika. hlm. 142.
} 
Konsep kepemilikan antara kepemilikan rumah biasa (landed house) berbeda dengan Strata Title, yaitu apabila seseorang membeli rumah biasa maka kepemilikan tersebut akan muncul dalam bentuk Sertipikat Hak Milik (SHM). Kepemilikan SHM berdasarkan UndangUndang Pokok Agraria (UUPA) sangat tegas dan permanen, meliputi kepemilikan tanah, tanah rumah tinggal, tanah di bawah bangunan dan bagian atas bangunan. Di saat yang sama, jika seseorang membeli apartemen, sertipikatnya bukanlah SHM layaknya rumah biasa, melainkan konsep kepemilikan Strata Title dalam bentuk Sertipikat Hak Milik atas Satuan Rumah Susun (SHMSRS). ${ }^{13}$

Sertipikat Hak Milik Atas Satuan Rumah Susun diterbitkan kepada setiap orang yang memenuhi persyaratan pemegang hak atas tanah dalam UUPA. Bagi pemilik unit rumah susun, akan diberikan bukti kepemilikan yang kuat dalam bentuk surat kepemilikan unit rumah susun yang diterbitkan oleh Dinas Pertanahan Kabupaten/ Kota, yang meliputi: ${ }^{14}$

a. Salinan Buku Tanah Dan Surat Ukur Atas Hak Tanah Bersama Sesuai Dengan Ketentuan Peraturan Perundang-Undangan;

b. Gambar Denah Lantai Pada Tingkat Rumah Susun Bersangkutan Yang Menunjukkan Sarusun Yang Dimiliki; dan

c. Pertelaan mengenai besarnya bagian hak atas bagian bersama, benda bersama, dan tanah bersama bagi yang bersangkutan.

Sejak akta pemisahan didaftarkan melalui penyusunan buku tanah untuk masing-masing unit rumah susun yang bersangkutan, maka kepemilikan satuan rumah susun tersebut telah dinyatakan. Tujuan penerbitan sertipikat kepemilikan unit rumah susun adalah untuk memastikan kepastian hukum dan kepastian kepemilikan unit rumah susun. ${ }^{15}$ Namun pada kenyataannya permasalahan yang terjadi adalah perusahaan pengembang apartemen sering kali melanggar hukum, seperti tidak menyediakan SHMSRS. Akibatnya, proses pengalihan unit apartemen tanpa sertipikat memiliki risiko tinggi dan kerapuhan hukum. Bagi pemilik unit apartemen, keberadaan perlindungan hukum sangat diperlukan, karena banyak pengembang yang hanya fokus pada keuntungan perusahaan pengembang.

Pada kasus Apartemen Casa Grande Residence dimana PT. Elite Prima Hutama (EPH) yang merupakan pengembang Apartemen Casa Grande Residence yang terletak di Jalan Casablanca Raya Kav. 88, Menteng Dalam, Kecamatan Tebet, Kota Jakarta Selatan. Antara PT.

\footnotetext{
${ }^{13}$ Ibid., hlm. 146.

${ }^{14}$ Dhaniswara K, Harjono. (2016). Hukum Properti. Jakarta: Pusat Pengembangan Hukum dan Bisnis Indonesia. hlm. 199

${ }^{15}$ Ibid., hlm. 211.
} 
Elite Prima Hutama selaku pengembang dengan Alia Febyani telah menandatangani Perjanjian Pengikatan Jual Beli (PPJB) Pembelian Unit Apartemen Casa Grande Residence Lantai 17 Unit 11 Type NO Tertanggal 27 September 2012 dan Perjanjian Pengikatan Jual Beli (PPJB) Pembelian Unit Apartemen Casa Grande Residence Lantai 22 Unit 09 Type NQ Tertanggal 20 Maret 2014. Pembelian Unit Apartemen Casa Grande Residence Tower Montana oleh penghuni dilakukan dengan menggunakan fasilitas kredit yang diterbitkan PT. BANK CIMB NIAGA, Tbk., yang mana antara penghuni dan PT. BANK CIMB NIAGA, Tbk., telah menandatangani Perjanjian Kredit Perihal Pemberian Fasilitas Kredit untuk pembelian 2 (dua) unit Apartemen tersebut. Dan pada tanggal 27 September 2012, pengembang telah mengirim surat kepada PT. BANK CIMB NIAGA, Tbk., yang menjelaskan bahwa pengembang akan melakukan proses pemecahan dan penerbitan Sertipikat Hak Milik atas Satuan Rumah Susun (SHMSRS) atas unit apartemen yang dibeli selambat-lambatnya selesai 36 (tiga puluh enam) bulan sejak serah terima unit apartemen.

Namun hingga saat ini, penghuni tidak pernah mendapatkan pemberitahuan dari pengembang kapan dilaksanakannya penandatangan Akta Jual Beli untuk menentukan estimasi jangka waktu perolehan Sertipikat Hak Milik atas Satuan Rumah Susun (SHMSRS). Dengan tidak memberikan kepastian hukum mengenai penerbitan sertifikat dan tidak memberikan informasi yang pasti dan jelas mengenai proses penandatangan Akta Jual Beli serta janji yang tidak pasti/tidak sesuai telah mengalami kerugian berupa yang sangat besar yaitu Rp. 1.095.000.000,- (satu milyar sembilan puluh lima juta rupiah) dan selain kerugian materiil, akibat dari Perbuatan Melawan Hukum penghuni juga telah menyebabkan kerugian immateriil bagi penghuni yaitu dengan menaruh investasi dalam bentuk deposito atas uang sebesar Rp. 3.095.000.000,- maka dengan bunga 6\% (enam persen) per tahun, penghuni akan mendapat keuntungan bunga sebesar Rp. 185.700.000,- per tahun, sehingga total dalam 6 tahun akan mendapatkan keuntungan sebesar Rp. 1.114.200.000,- secara beban psikologis akibat terperdaya oleh iklan dan/atau promosi investasi apartemen yang menguntungkan.

Namun kenyataannya penghuni tidak mendapatkan informasi yang sebenarnya dari pihak pengembang tentang kapan waktu untuk penandatangan Akta Jual Beli dan kepastian akan keuntungan investasi atas unit apartemen yang belum terjual juga mengakibatkan kerugian immateriil bagi penghuni sebesar Rp. 10.000.000.000,- (sepuluh milyar rupiah). Maka atas hal tersebut diatas pihak pembeli menghukum pengembang untuk membayar Kerugian Materiil yang diderita pembeli sebesar Rp. 1.095.000.000,- (satu milyar sembilan puluh lima juta rupiah) dan Kerugian Immateriil sebesar Rp. 11.114.200.000,- (sebelas milyar seratus empat belas juta dua 
ratus ribu rupiah). Berikut ini adalah bentuk perlindungan hukum bagi pemilik satuan rumah susun:

\section{a. Ditinjau dari Burgelijk Wetboek (BW)}

Pada kasus pembelian unit Apartemen Casa Grande antara Alia Febyani dengan PT. Elite Prima Hutama dapat dikatakan suatu perbuatan melawan hukum. Perbuatan Melawan Hukum secara luas tidak hanya pada saat melanggar undang-undang, namun juga bertentangan dengan kewajiban hukum si pelaku, bertentangan dengan hak subyektif orang lain, bertentangan dengan kesusilaan, dan bertentangan dengan kepatutan, ketelitian dan kehati-hatian. Secara prinsip dalam BW Pasal 1365 dinyatakan bahwa "setiap perbuatan melawan hukum yang oleh karena itu menimbulkan kerugian pada orang lain, mewajibkan orang yang karena kesalahannya menyebabkan kerugian tersebut mengganti kerugian”. Dari ketentuan Pasal 1365 BW ini, dapat diketahui bahwa suatu perbuatan melawan hukum baru dapat dituntut penggantian kerugian apabila telah memenuhi unsur-unsur sebagai berikut: ${ }^{16}$

1) Unsur pertama; adanya suatu perbuatan

Perbuatan disini berarti bahwa pelaku melakukan sesuatu dalam arti aktif atau tidak melakukan apa pun dalam arti pasif. ${ }^{17}$ Dalam hal pihak pengembang tidak memberikan informasi kepada penghuni tentang penandatanganan Akta Jual Beli, maka tidak pasti kapan mereka bisa mendapatkan Sertipikat Hak Milik atas Satuan Rumah Susun (SHMSRS), berarti ada tindakan disini, yaitu tindakan dalam arti pasif, yang berarti pihak pengembang tidak melakukan apa pun. Dimana pihak pengembang tidak melakukan sesuatu yang diwajibkan oleh undang-undang, sebagaimana kepemilikan atas sarusun dijelaskan pada Pasal 47 ayat (1) Undang-Undang Rumah Susun, "Sebagai tanda bukti hak kepemilikan atas sarusun diatas tanah hak pengelolaan diterbitkan SHM Sarusun".

2) Unsur kedua; perbuatan tersebut melawan hukum

Sejak tahun 1919, perbuatan melawan hukum tidak lagi dimaknai sebagai hanya bertentangan dengan kewajiban hukum, tetapi telah didefinisikan secara luas, antara lain:

a) Tindakan yang melanggar hak orang lain.

b) Tindakan yang melanggar kewajiban hukum mereka sendiri

c) Tindakan yang melanggar kesusilaan.

d) Tindakan yang melanggar dkehati-hatian atau keharusan dalam pergaulan masyarakat yang baik. ${ }^{18}$

\footnotetext{
${ }^{16}$ P.N.H. Simanjuntak. (2016). Hukum Perdata Indonesia. Jakarta: Prenadamedia Group. hlm. 304

${ }^{17}$ MA. Moegni Djojodirjo. (1982). Perbuatan Melawan Hukum. Jakarta: Pradnya Paramita. hlm. 13.

${ }^{18}$ Munir Fuady. (2005). Perbuatan Melawan Hukum: Pendekatan Kontemporer. Bandung: PT Citra Aditya Bakti. hlm. 6.
} 
Perbuatan melawan hukum diartikan sebagai tindakan yang melanggar hak orang lain. Dalam hal ini hak orang lain mengacu pada hak subjektif orang lain yang terikat oleh hukum. Oleh karena itu, hak subjektif di sini dibatasi pada sejumlah hak yang disebutkan dalam undangundang saja. ${ }^{19}$ Dalam hal pihak pengembang yang tidak menerbitkan Sertipikat Hak Milik atas Satuan Rumah Susun (SHMSRS) terhitung sejak serah-terima Apartemen hingga saat ini. Maka ada tindakan yang melanggar hak orang lain, yaitu hak atas pemilik satuan rumah susun yang tidak diterbitkan sertipikat sebab kewajiban pihak pengembang untuk menerbitkan SHMSRS dimaksudkan untuk memberi perlindungan hukum bagi pemilik hak atas satuan rumah susun, artinya ada hak subjektif orang lain yang diatur dalam undang-undang.

Dalam pengertian kedua, pelanggaran terhadap kewajiban hukum pribadi atau pelanggaran kewajiban hukum pelaku tidak hanya berurusan dengan norma-norma yang "dilarang", tetapi juga berurusan dengan norma-norma "memerintah (mewajibkan, mengharuskan). ${ }^{20}$ Untuk pengertian yang kedua, pihak pengembang tidak menerbitkan SHMSRS sehingga tanpa sertipikat kepemilikan unit apartemen, sulit bagi penghuni untuk menjual atau mengalihkan unit apartemen. Maka dapat dikatakan pihak pengembang telah melakukan perbuatan melawan hukum, sebab berdasarkan Pasal 47 ayat (1) Undang-Undang Rumah Susun, "sebagai tanda bukti kepemilikan atas sarusun diatas tanah hak milik, hak guna bangunan, atau hak pakai di atas tanah negara, hak guna bangunan atau hak pakai di atas tanah hak pengelolaan diterbitkan Sertipikat Hak Milik atas Satuan Rumah Susun”.

Mengenai definisi ketiga, perbuatan melawan hukum diartikan sebagai tindakan yang melanggar kesusilaan, jelas tindakan yang dilakukan merupakan tindakan yang melanggar kesusilaan sebab pihak pengembang yang tidak menerbitkan Sertipikat sebagai tanda bukti hak kepemilikan atas satuan rumah susun.

Definisi keempat, bahwa perbuatan melawan hukum berarti tindakan yang melanggar kehati-hatian atau keharusan dalam pergaulan masyarakat yang baik, karena kewajiban pihak pengembang untuk menerbitkan Sertipikat sebagai bukti hak kepemilikan atas satuan rumah susun terkait dengan pergaulan pihak pengembang dalam masyarakat bahkan banyak pihak pengembang yang seringkali meremehkan untuk melakukan penerbitkan SHMSRS. Bahkan pihak pengembang dengan sengaja untuk tidak melakukan penerbitan SHMSRS dengan tujuan untuk mendapatkan keuntungan bagi perusahaan pengembang.

3) Unsur ketiga; adanya kesalahan dari pihak pelaku.

\footnotetext{
${ }^{19}$ J. Satrio. (1993). Hukum Perikatan: Perikatan yang Lahir dari Undang-undang. Bandung: PT Citra Aditya Bakti. hlm. 168

${ }^{20}$ Ibid, hlm. 182
} 
Menurut Pasal 1365 BW, untuk menyebut suatu perbuatan sebagai perbuatan melawan hukum, harus ada unsur kesalahan. Suatu tindakan dianggap oleh hukum mengandung unsur kesalahan dapat dimintai pertanggungjawaban secara hukum jika dipenuhi unsur-unsur sebagai berikut: ${ }^{21}$

1. Unsur kesengajaan;

2. Kelalaian (culpa); dan

3. Tidak ada alasan pembenar atau alasan pemaaf, seperti overmacht.

Oleh karena itu, Perbuatan pihak pengembang yang tidak menerbitkan Sertifikat atas kepemilikan hak satuan rumah susun telah memenuhi unsur ketiga yaitu adanya kesalahan dalam arti disengaja atau lalai dimana perbuatan yang telah dilakukan tidak ada alasan pembenar atau alasan pemaaf, maka tindakan pengembang yang tidak menerbitkan Sertipikat melanggar ketentuan Pasal 47 ayat (2) Undang-Undang Rumah Susun yang mewajibkan pihak pengembang untuk Sertifikat Hak Milik atas Satuan Rumah Susun diterbitkan bagi setiap orang yang memenuhi syarat sebagai pemegang hak atas tanah.

4) Unsur keempat; adanya kerugian bagi korban

Adanya kerugian (schade) bagi korban juga merupakan syarat, sehingga dapat digunakan gugatan berdasarkan Pasal 1365 BW. Berbeda dengan kerugian wanprestrasi yang hanya mengenal kerugian materiil, maka kerugian karena perbuatan melawan hukum di samping kerugian materiil, juga tidak dapat dinilai dengan uang. ${ }^{22}$ Kerugian yang disebabkan oleh karena perbuatan melawan hukum dapat berupa kerugian materiil (dapat dinilai dengan uang) dan kerugian immateriil (tidak dapat dinilai dengan uang). Dalam hal pihak pengembang tidak menerbitkan Sertifikat Hak Milik atas Satuan Rumah Susun (SHMSRS) telah menimbulkan kerugian, berupa kerugian materiil dimana penghuni sangat sulit untuk mengalihkan Unit Apartemen maupun kerugian immateriil secara beban psikologis akibat terperdaya oleh iklan dan/atau promosi investasi apartemen yang menguntungkan.

5) Unsur kelima; adanya hubungan kausal antara perbuatan dengan kerugian.

Kerugian yang diakibatkan oleh pelaku haruslah kerugian yang disebabkan oleh perbuatan perilaku tersebut, bukan kerugian yang disebabkan oleh alasan lain. Dengan kata lain, ada hubungan sebab akibat antara kerugian dan perilaku pelaku. Pengembang yang tidak menerbitkan sertipikat sebagai tanda bukti hak kepemilikan atas sarusun menimbulkan kerugian

\footnotetext{
${ }^{21}$ Munir Fuadi, Op. Cit. hlm. 13-14.

22 Habibul Umam Taqiuddin, "Perbuatan Melawan Hukum Dalam Perspektif Hukum Perdata" http://indonesiasociety.lawyer/perbuatan-melawan-hukum-dalam-perspektif-hukum-perdatal, diakses tanggal 2 November 2020, Pukul 15.30 WIB.
} 
bagi orang lain, yaitu penghuni Apartemen. Dimana penghuni sangat sulit untuk menjual atau mengalihkan beberapa unit Apartemen yang dibeli. Sehingga ada hubungan sebab akibat antara perbuatan dan kerugian.

Dari uraian di atas dapat disimpulkan bahwa akibat dari perbuatan melawan hukum adalah kerugian. Kerugian yang ditimbulkan oleh perbuatan melawan hukum tersebut haruslah diganti oleh orang yang menyebabkan kerugian karena kesalahannya atau pelaku perbuatan melawan hukum tersebut. Oleh karena itu, Pasal 1365 BW mengatur tentang kewajiban kepada si pelaku perbuatan melawan hukum untuk mengganti atas kerugian yang ditimbulkannya. Adapun tuntutan yang dapat diajukan karena perbuatan melawan hukum:

1. Ganti rugi atas kerugian yang diderita dalam bentuk uang.

2. Ganti rugi dalam bentuk natura atau mengembalikan ke keadaan semula.

3. Pernyataan bahwa perbuatan yang dilakukan adalah melawan hukum.

4. Melarang dilakukannya perbuatan tertentu. ${ }^{23}$

Dalam hal ini penghuni mempunyai hak mengenai tuntutan yang dapat diajukan karena perbuatan melawan hukum yang dilakukan oleh pihak pengembang yaitu : Ganti rugi dalam bentuk uang atas kerugian yang ditimbulkan, bahwa tentang investasi yang menguntungkan sebagaimana dijanjikan oleh pihak pengembang tidak sesuai dan bahkan mengakibatkan penghuni mengalami kerugian materiil yang sangat besar yaitu Rp. 1.095.000.000,- (satu milyar sembilan puluh lima juta rupiah) dan selain kerugian materiil, akibat dari Perbuatan Melawan Hukum penghuni juga telah menyebabkan kerugian immateriil bagi penghuni yaitu dengan menaruh investasi dalam bentuk deposito atas uang sebesar Rp. 3.095.000.000,- maka dengan bunga 6\% (enam persen) per tahun, penghuni akan mendapat keuntungan bunga sebesar Rp. 185.700.000,- per tahun, sehingga total dalam 6 tahun akan mendapatkan keuntungan sebesar Rp. 1.114.200.000,- secara beban psikologis akibat terperdaya oleh iklan dan/atau promosi investasi apartemen yang menguntungkan.

Namun kenyataannya penghuni tidak mendapatkan informasi yang sebenarnya dari pihak pengembang tentang kapan waktu untuk penandatangan Akta Jual Beli dan kepastian akan keuntungan investasi atas unit apartemen yang belum terjual juga mengakibatkan kerugian immateriil bagi penghuni sebesar Rp. 10.000.000.000,- (sepuluh milyar rupiah). Maka atas hal tersebut diatas pihak pembeli menghukum pengembang untuk membayar Kerugian Materiil yang diderita pembeli sebesar Rp. 1.095.000.000,- (satu milyar sembilan puluh lima juta rupiah) dan

\footnotetext{
${ }^{23}$ Slamet, Sri Redjeki Slamet. (2013). Tuntutan Ganti Rugi Dalam Perbuatan Melawan Hukum: Suatu Perbandingan Dengan Wanprestasi. Lex Jurnalica Volume 10 Nomor 2.
} 
Kerugian Immateriil sebesar Rp. 11.114.200.00,- (sebelas milyar seratus empat belas juta dua ratus ribu rupiah).

\section{b. Ditinjau dari Undang-Undang No. 20 Tahun 2011 tentang Rumah Susun (UURS)}

\section{1) Pasal 47 ayat (2) Undang- Undang Rumah Susun}

"Sertipikat Hak Milik atas Satuan Rumah Susun sebagaimana dimaksud pada ayat (1) diterbitkan bagi setiap orang yang memenuhi syarat sebagai pemegang hak atas tanah." Dalam hal ini sebagaimana dimaksud dalam Pasal 47 ayat (2), penghuni yang memenuhi persyaratan pemegang hak atas tanah berhak atas SHMSRS. Namun nyatanya, meski penghuni sudah memenuhi persyaratan yang ditetapkan pengembang, yang terjadi pada Apartemen Casa Grande Residence, pengembang tidak memberikan sertipikat.

Pihak penghuni Apartemen Casa Grande Residence telah melakukan pemenuhan administraif pembelian dengan menggunakan fasilitas kredit yang diterbitkan PT. Bank Cimb Niaga, Tbk, yang mana antara konsumen dan PT. Bank Cimb Niaga, Tbk. telah menandatangani Perjanjian Kredit Perihal Pemberian Fasilitas Kredit untuk pembelian 2 (dua) unit Aparteman. Penghuni selalu meminta agar sertipikat hak milik satuan rumah susun yang menjadi hak mereka untuk segera diberikan tetapi tidak pernah mendapatkan pemberitahuan dari pihak pengembang kapan dilaksanakannya penandatangan Akta Jual Beli untuk menentukan perkiraan jangka waktu mendapatkan Sertipikat Hak Milik atas unit Apartemen yang dibeli, yang ternyata kemudian PT. Bank Cimb Niaga, Tbk. memberitahukan bahwa pihak pengembang telah mengirimkan Surat Nomor 212/LGL/CGR-EPH/IX/2012 yang menyatakan pengembang akan melakukan proses pemecahan dan penerbitan SHMSRS atas unit apartemen selambat-lambatnya selesai 36 bulan sejak serah terima unit Apartemen. Namun hingga saat ini antara penghuni dan pengembang belum juga dilaksanakan proses penandatanganan Akta Jual Beli sehingga tidak ada kepastian kapan akan menerbitkan Sertipikat.

Bahkan berbagai teguran juga sudah dilakukan oleh penghuni yang telah meminta pihak pengembang melalui Surat Somasi Nomor 04-5/ARPM-Som/IV/2019 Tanggal 18 April 2019 dan Surat Somasi Nomor 04-9/ARPM-Som/IV/2019 Tanggal 29 April 2019, untuk segera mengklarifikasi terkait Surat Nomor 212/LGL/CGR-EPH/IX/2012 Tanggal 27 September 2012 yang pada pokoknya meminta penjelasan penandatanganan Akta Jual Beli dihadapan Notaris/PPAT yang berwenang. Namun hingga saat ini, penghuni Apartemen Casa Grande Residence belum mendapatkan haknya setelah memenuhi kewajibannya sebagai konsumen. Dengan demikian PT. Elite Prima Hutama (Pakuwon Group) selaku pengembang telah melanggar 
ketentuan Pasal 47 ayat (2) Undang-Undang Rumah Susun. Dan harus segera memberikan sertipikat kepemilikan unit apartemen kepada Alia Febyani, penghuni Apartemen Casa Grande Residence yang memenuhi syarat.

\section{c. Ditinjau dari Undang-Undang Nomor 8 Tahun 1999 tentang Perlindungan Konsumen (UUPK)}

\section{1) Pasal 3 angka 4 Undang-Undang Perlindungan Konsumen}

"Perlindungan Konsumen bertujuan untuk menciptakan sistem perlindungan konsumen yang mengandung unsur kepastian hukum dan keterbukaan informasi serta akses untuk mendapatkan informasi."

Setiap konsumen berhak atas kepastian hukum dan hak keterbukaan informasi sesuai dengan kesepakatan kedua belah pihak, dan hak untuk memperoleh informasi dari pelaku usaha. Namun, kenyataannya yang terjadi pada Apartemen Casa Grande Residence bahwa pihak pengembang tidak memberikan informasi yang pasti dan jelas kepada penghuni untuk mendapatkan kepastian kapan proses penandatanganan Akta Jual Beli. Dalam hal ini penghuni yang tidak memperoleh informasi yang pasti dan jelas kapan akan melaksanakan proses penandatanganan Akta Jual Beli sudah berupaya untuk menuntut hak mereka sebagai konsumen. Salah satu upaya yang telah penghuni lakukan misalnya konsumen telah meminta kepada pihak pengembang namun hingga saat ini konsumen belum mendapatkan haknya.

Oleh karena itu, menurut penulis hal tersebut melanggar Pasal 3 ayat 4 Undang-Undang Perlindungan Konsumen. Pelaku usaha (dalam hal ini pengembang) tidak memberikan keterbukaan informasi kapan akan melaksanakan proses penandatanganan Akta Jual Beli sehingga tidak ada kepastian kapan mendapatkan Sertipikat Hak Milik atas Satuan Rumah Sususn (SMHSRS) sebagai kepastian hukum kepemilikan atas satuan rumah susun yang seharusnya sudah diterbitkan setelah konsumen melunasi kewajibannya (yaitu, kewajiban yang telah disepakati dibayar). Namun hingga saat ini konsumen belum mendapatkan hak yang layak mereka dapatkan setelah memenuhi kewajibannya sebagai konsumen. Para pengembang tampaknya mengabaikan aturan dalam undang-undang perlindungan konsumen dan peringatan yang dikeluarkan pihak konsumen.

\section{2) Pasal 4 angka 3 Undang-Undang Perlindungan Konsumen}

"Hak atas informasi yang benar, jelas, dan jujur mengenai kondisi dan jaminan barang dan/atau jasa." Setiap konsumen berhak memperoleh informasi yang benar, jelas dan jujur tentang kondisi dan jaminan barang dan / atau jasa yang disediakan oleh pelaku komersial. Namun, yang 
terjadi pada Apartemen Casa Grande Residence adalah pengembang apartemen melanggar ketentuan pasal ini karena pengembang tidak memberikan informasi yang benar dan jelas tentang pelaksanaan proses penandatanganan Akta Jual Beli untuk menentukan perkiraan batas waktu pengurusan Sertipikat Hak Milik atas Satuan Rumah Susun (SHMSRS). Sejak penandatanganan Perjanjian Pengikatan Jual Beli (PPJB) Unit Apartemen antara pihak penghuni dengan pihak pengembang Apartmen, pihak penghuni tidak pernah mendapatkan pemberitahuan apapun mengenai penandatanganan Akta Jual Beli, kemudian PT. Bank Cimb Niaga, Tbk memberitahukan bahwa pihak pengembang telah mengirim Surat Nomor: 212/LGL/CGREPH/IX/2012 yang menyatakan pihak pengembang akan melakukan proses pemecahan dan penerbitan Sertipikat Hak Milik atas Satuan Rumah Susun (SHMSRS) selambat-lambatnya selesai 36 bulan sejak serah terima unit apartemen.

Pengembang tidak sejujurnya memberikan detail dan informasi penerbitan sertipikat properti unit apartemen yang seharusnya diterima pada 2015 sebagaimana informasi dari pihak pengembang yang akan melakukan proses pemecahan dan penerbitan sertipikat selambatlambatnya 36 bulan sejak serah terima unit apartemen. Bahkan sejak awal penandatanganan perjanjian jual beli unit apartemen (PPJB), konsumen sudah meminta sertipikat kepemilikan unit rumah susun tersebut. Dalam hal pengembang tidak jujur tentang kejelasan sertipikat kepemilikan unit yang diberikan kepada konsumen telah melanggar Pasal 4 ayat 3 Undang-Undang Perlindungan Konsumen.

\section{3) Pasal 9 ayat (1) huruf $k$ Undang-Undang Perlindungan Konsumen.}

"Pelaku usaha dilarang menawarkan, mempromosikan, mengiklankan suatu barang dan/atau jasa secara tidak benar, dan/atau seolah-olah menawarkan sesuatu yang mengandung janji yang belum pasti." Pelaku usaha dalam hal ini PT. Elite Elite Prima Hutama selaku pengembang Apartemen Casa Grande Residence dilarang memberikan, mempromosikan, mengiklankan barang dan / atau jasa secara tidak benar, dan / atau memberikan hal-hal yang mengandung janji yang tidak pasti. Artinya, untuk promosi / periklanan yang dilakukan oleh pengembang mengenai investasi menguntungkan yang ditawarkan saat menjual apartemen.

Namun kenyataannya penghuni menderita kerugian materiil secara nyata pada saat penjualan 1 (satu) unit Apartemen Casa Grande Residence Tower Montana Lantai 22 Unit 09 Type NQ yang dijual pada bulan Maret 2019 hanya terjual seharga Rp. 2.000.000.000,- (dua milyar rupiah) jauh di bawah dari harga pada saat penghuni membeli dengan harga Rp.3.095.000.000,- (tiga milyar sembilan puluh lima juta rupiah), yang mana tidak sesuai dengan janji yang diberikan oleh pihak pengembang kepada penghuni tentang investasi yang 
menguntungkan. Dimana apabila dengan menaruh investasi dalam bentuk deposito atas uang sebesar Rp. 3.095.000.000,- maka dengan bunga 6\% (enam persen) / per tahun, penghuni akan mendapat keuntungan bunga sebesar Rp. 185.700.000,- (seratus delapan puluh lima juta tujuh ratus ribu rupiah)/per tahun, sehingga total dalam 6 (enam) tahun akan mendapatkan keuntungan bunga sebesar Rp. 1.114.200.000,- (satu milyar seratus empat belas juta dua ratus ribu rupiah). Tetapi penghuni justru mengalami kerugian materiil yaitu Rp. 1.095.000.000,- (satu milyar sembilan puluh lima juta rupiah).

Oleh karena itu, PT Elite Prima Hutama selaku pengembang melanggar ketentuan Pasal 9 ayat (1) k Undang-Undang Perlindungan Konsumen. Karena pengembang menawarkan, mempromosikan, mengiklankan suatu barang dan/atau jasa secara tidak benar, atau seolah-olah menawarkan sesuatu yang mengandung janji yang belum pasti mengenai investasi yang menguntungkan.

\section{PROSES PERALIHAN HAK MILIK ATAS SATUAN RUMAH SUSUN TANPA SERTIPIKAT}

Salah satu kepemilikan unit apartemen oleh pemilik unit apartemen terkait dengan pengalihan kepemilikan unit apartemen dari pemiliknya kepada pihak lain. Menurut ketentuan Hukum Tanah Nasional yaitu (UU No. 5 Tahun 1960 tentang UUPA) telah mengatur mengenai semua Peralihan Hak Milik Atas Satuan Rumah Susun melalui jual beli, tukar menukar, hibah, pemasukan dalam perusahaan dan perbuatan hukum pemindahan hak lainnya, kecuali untuk pengalihan hak melalui lelang, hanya dapat didaftarkan jika disertifikasi oleh kontrak yang ditandatangani oleh PPAT sesuai dengan hukum dan peraturan yang berlaku.

Menurut Pasal 43 Undang-Undang Rumah Susun "Proses jual beli sarusun sebelum pembangunan rumah susun selesai dapat dilakukan melalui PPJB yang dibuat di hadapan pejabat yang berwenang yaitu Notaris”. Mengenai pembangunan rumah susun yang sudah dilaksanakan dapat dilakukan dengan adanya sertipikat laik fungsi dan sertipikat hak milik satuan rumah susun dan sertipikat kepemilikan bangunan gedung satuan rumah susun sebagai tanda. Penguasaan rumah susun komersial dapat dimiliki dengan jual beli atau sewa. ${ }^{24}$

Pada kasus Apartemen Casa Grande Residence antara pengembang dan pembeli telah menandatangani Perjanjian Pengikatan Jual Beli (PPJB) pembelian unit Apartemen Casa Grande Residence Tower Montana Lantai 17 Unit 11 Type NO Tertanggal 27 September 2012 yang di Waarmeking oleh Buntario Tigris, S.H., S.E., M.H, Notaris di Jakarta Pusat, dengan Nomor

\footnotetext{
${ }^{24}$ Suriansyah Murhaini. (2015). Hukum Rumah Susun. Jakarta: Laksbang Grafika. hlm. 90
} 
4.267/IX/2012/W dan Perjanjian Pengikatan Jual Beli (PPJB) Pembelian unit Apartemen Casa Grande Residence Tower Montana Lantai 22 Unit 09 Type NQ Tertanggal 20 Maret 2014 yang di Waarmeking oleh Buntario Tigrid, S.H., S.E., M.H, Notaris di Jakarta Pusat, dengan Nomor 5.580/III/2014/W. Namun hingga saat ini pembeli tidak pernah mendapatkan pemberitahuan dari pihak pengembang kapan akan dilaksanakannya penandatanganan Akta Jual Beli (AJB) untuk menentukan perkiraan jangka waktu mendapatkan Sertipikat Hak Milik atas Satuan Rumah Susun (SHMSRS) atas unit Apartemen, dikarenakan perbuatan pengembang yang tidak memberikan kepastian hukum mengenai proses penandatanganan AJB, mengakibatkan pihak pembeli sangat sulit untuk melakukan jual beli atau mengalihkan beberapa unit Apartemen yang dibeli dengan tidak adanya AJB.

Menurut Pasal 1457 BW, jual beli adalah kesepakatan di mana salah satu pihak harus menyerahkan benda tersebut dan pihak lain harus membayar harga yang disepakati. Pengikatan jual beli antara pengembang sebagai kreditur dan pembeli sebagai debitur bertujuan untuk membayar penjual dan mengikat kedua belah pihak. Secara bertahap, hingga pihak pertama menyelesaikan pembangunan dan menyerahkannya kepada pihak kedua, hingga tercapai perjanjian jual beli yang dibuat dihadapan Notaris. ${ }^{25}$ Menurut Pasal 44 Undang-Undang Rumah Susun, mengenai pengalihan rumah susun menyatakan bahwa: ${ }^{26}$

1. Proses jual beli setelah penyelesaian rumah susun dilakukan melalui Akta Jual Beli (AJB);

2. Pembangunan Rumah Susun dinyatakan selesai sebagaimana dimaksud pada ayat (1) apabila telah diterbitkan;

3. Sertipikat laik fungsi; dan

4. SHM atas Sarusun atau SKBG (Sertipikat Kepemilikan Bangunan Gedung) atau Sarusun.

Unsur jual beli Rumah Susun dilakukan oleh pihak pengembang dan pembeli. Penandatanganan Akta Jual Beli masing-masing unit dilakukan di hadapan notaris. Badan Pertanahan Nasional atau Kantor Pertanahan juga berpartisipasi dalam proses jual beli. Hal ini terkait dengan proses penerbitan SHMSRS dan pengalihan nama unit apartemen kepada masingmasing pembeli oleh kantor BPN. ${ }^{27}$ Namun sejak 2012 serah terima unit Apartemen hingga saat ini antara pihak pengembang dan pihak pembeli belum dilaksanakan proses penandatanganan Akta Jual Beli yang mengakibatkan tidak ada kepastian kapan akan dilakukan penerbitan

\footnotetext{
${ }^{25}$ Ahmad Miru \& Sutarman Yodo. (2015). Hukum Perlindungan Konsumen, Cetakan Kesembilan. Jakarta: Raja Grafindo Persada. hlm. 44

26 Pongantung, Rio Y. (2018). Perjanjian Pengikatan Jual Beli Oleh Para Pihak Menurut Undang-Undang Nomor 20 Tahun 2011 Tentang Rumah Susun. Lex Privatum Volume VI Nomor 10.

${ }^{27}$ Urip Santoso. (2017). Hak Atas Tanah, Hak Pengelolaan \& Hak Milik Atas Satuan Rumah Susun. Jakarta: Kencana. hlm. 177
} 
sertipikat hak atas sarusun dan proses balik nama satuan Rumah Susun. Sehingga pembeli melakukan proses jual beli unit apartemen dengan Perjanian Pengikatan Jual Beli (PPJB) yang dijadikan sebagai dasar jual beli. Maka penjual harus menawarkan properti di bawah harga pasar atau harga yang ditawarkan oleh pengembang. ${ }^{28}$ Yang mana pada saat proses penjualan 1 (satu) Apartemen Casa Grande Residence Tower Montana Lantai 22 Unit 09 Type NQ milik penjual yang dijual pada bulan Maret 2019 hanya terjual seharga Rp. 2.000.000.000,- (dua milyar rupiah) jauh di bawah dari harga pada saat penjual membeli dari pengembang dengan harga Rp. 3.095.000.000,- (tiga milyar sembilan puluh lima juta rupiah).

Dalam hal ini jual beli atas unit Apartemen atas dasar PPJB dengan tidak adanya proses penandatangan Akta Jual Beli sehingga tidak ada kepastian kapan mendapatkan Sertipikat hak milik satuan rumah susun (SHMSRS) karena pengembang telah dengan sengaja tidak melakukan proses penandatanganan sejak awal serah terima unit Apartemen. Meskipun PPJB mempunyai payung hukum, yaitu melalui UU No. 1 Tahun 2011 tentang Sistem Perjanjian Pendahuluan Jual Beli Rumah yang memungkinkan adanya suatu perjanjian pendahuluan terkait transaksi jual beli untuk objek rumah atau rumah susun, bahkan ditegaskan juga melalui SEMA No. 4 Tahun 2016 yang menyebutkan bahwa PPJB dapat terjadi apabila dalam kondisi telah ada pembayaran lunas dari pembeli serta telah ada penguasaan terhadap objek, dan Peraturan Menteri Pekerjaan Umum Dan Perumahan Rakyat Republik Indonesia Nomor 11/Prt/M/2019 Tentang Sistem Perjanjian Pendahuluan Jual Beli Rumah bahwa PPJB telah ditandatangani oleh calon pembeli dan pelaku pembangunan yang dibuat di hadapan notaris. ${ }^{29}$

Namun tetap kepemilikan atas satuan rumah susun diatas tanah hak guna bangunan dalaam hal ini Unit Apartemen harus diterbitkan Sertipikat Hak Milik atas Satuan Rumah Susun sebab berdasarkan Pasal 47 ayat (1) Undang-Undang Rumah Susun, "sebagai tanda bukti kepemilikan atas sarusun diatas tanah hak milik, hak guna bangunan, atau hak pakai di atas tanah negara, hak guna bangunan atau hak pakai di atas tanah hak pengelolaan diterbitkan Sertipikat Hak Milik atas Satuan Rumah Susun”. Dengan demikian, proses jual beli unit Apartemen Casa Grande Residence atas dasar PPJB tanpa proses penandatangan AJB sehingga tidak ada kepastian kapan mendapatkan Sertipikat adalah tidak sah.

28 Lita Lia "Bolehkah Jual Apartemen dengan Dasar PPJB Apartemen Bukan AJB?" https://blog.spacestock.com/ppjb-apartemen/, diakses 07 November 2020, Pukul 19.56 WIB

${ }^{29}$ Denara, Made Ara Denara., I made Dedy Priyanto. (2019). Perjanjian Pengikatan Jual Beli (PPJB) Dalam Tramsaksi Peralihan Hak Atas Tanah dan/atau Bangunan. Kertha Semaya Volume 8 Nomor 1. 


\section{PENUTUP}

\section{KESIMPULAN}

Pelaku usaha dalam hal ini PT. Elite Prima Hutama selaku pengembang Apartemen Casa Grande Residence telah melakukan perbuatan melawan hukum dengan sengaja tidak melakukan proses penandatangan Akta Jual Beli sehingga tidak ada kepastian kapan akan mendapatkan Sertipikat hak milik satuan rumah susun telah memenuhi kelima unsur dalam Pasal 1365 BW juga telah melanggar beberapa ketentuan hukum yang berlaku, antara lain pasal 47 ayat (2) Undang-Undang Rumah Susun. Pasal 3 angka 4, Pasal 4 angka 3, dan pasal 9 ayat (1) huruf k Undang-Undang Perlindungan Konsumen. Maka jual beli Apartemen Casa Grande Residence yang hanya melakukan penandatanganan Perjanjian Pengikatan Jual Beli (PPJB) di Waarmeking oleh Buntario Tigris, S.H., S.E., M.H, Notaris di Jakarta Pusat, tetap tidak sah menurut hukum. Meskipun PPJB mempunyai payung hukum, yaitu melalui Undang-Undang Nomor 1 Tahun 2011 tentang Sistem Perjanjian Pendahuluan Jual Beli Rumah yang memungkinkan adanya suatu perjanjian pendahuluan terkait transaksi jual beli untuk objek rumah atau rusun (rumah susun), bahkan ditegaskan juga melalui SEMA Nomor 4 Tahun 2016 yang menyebutkan bahwa PPJB dapat terjadi apabila dalam kondisi telah ada pembayaran lunas dari pembeli serta telah ada penguasaan terhadap objek, dan Peraturan Menteri Pekerjaan Umum Dan Perumahan Rakyat Republik Indonesia Nomor 11/Prt/M/2019 Tentang Sistem Perjanjian Pendahuluan Jual Beli Rumah bahwa PPJB telah ditandatangani oleh calon pembeli dan pelaku pembangunan yang dibuat di hadapan notaris. Namun tetap berdasarkan Pasal 47 ayat (1) Undang-Undang Rumah Susun, "sebagai tanda bukti kepemilikan atas sarusun diatas tanah hak milik, hak guna bangunan, atau hak pakai di atas tanah negara, hak guna bangunan atau hak pakai di atas tanah hak pengelolaan diterbitkan Sertipikat Hak Milik atas Satuan Rumah Susun”.

\section{SARAN}

Pelaku Usaha dalam hal ini PT. Elite Prima Hutama harus segera memberikan hak-hak konsumen Apartemen Casa Grande Residence sesuai apa yang sudah diperjanjikan sejak awal terjadinya serah terima unit Apartement agar penghuni Apartemen Casa Grande Residence selaku konsumen merasa dihargai. Pihak pengembang juga seharusnya memberikan informasi yang sejelas-jelasnya mengenai proses penandatanganan Akta Jual Beli agar penghuni dapat memperoleh haknya berupa Sertipikat sehingga penghuni tidak merasa kesulitan untuk menjual atau mengalihkan unit Apartemen Casa Grande Residence yang dibelinya. 
Seharusnya pemerintah ikut serta secara langsung dalam penyelesaian kasus ini, kasus ini sudah berlangsung lama namun belum terselesaikan. Pemerintah juga harus memberikan sanksi tegas kepada PT. Elite Prima Hutama merupakan pengembang yang tidak kunjung memberikan sertipikat hak milik satuan rumah susun sehingga pengembang lain yang sengaja memperlambat penerbitan sertipikat kepemilikan unit apartemen tidak akan terulang kembali. Dibuatnya undangundang yang mengatur secara jelas mengenai sertipikat hak milik atas satuan rumah susun dan memberikan sanksi kepada pihak-pihak yang dengan sengaja melanggar ketentuan.

\section{DAFTAR PUSTAKA}

\section{Peraturan Perundang-Undangan:}

Undang-Undang Dasar Negara Republik Indonesia Tahun 1945

Burgelijk Wetboek (BW)

Republik Indonesia, Undang-Undang Nomor 5 Tahun 1960 Tentang Peraturan Dasar PokokPokok Agraria, Lembaran Negara No. 104 tahun 1960, Tambahan Lembaran Negara No. 2043.

Republik Indonesia, Undang-Undang Nomor 8 Tahun 1999 Tentang Perlindungan Konsumen, Lembaran Negara Nomor 22 tahun 1999, Tambahan Lembaran Negara Nomor 3821.

Republik Indonesia, Undang-Undang Nomor 39 Tahun 1999 Tentang Hak Asasi Manusia, Lembaran Negara Nomor 165 tahun 1999, Tambahan Lembaran Negara Nomor 3886.

Republik Indonesia, Undang-Undang Nomor 1 Tahun 2011 Tentang Perumahan dan Kawasan Permukiman, Lembaran Negara Nomor 7 tahun 2011, Tambahan Lembaran Negara Nomor 5188.

Republik Indonesia, Undang-Undang Nomor 20 Tahun 2011 Tentang Rumah Susun, Lembaran Negara Nomor 108 tahun 2011, Tambahan Lembaran Negara Nomor 5252.

Republik Indonesia, Peraturan Pemerintah Nomor 4 Tahun 1988 tentang Rumah Susun, Lembaran Negara Nomor 7 tahun 1988, Tambahan Lembaran Negara Nomor 3372.

\section{Buku:}

Ali Zainuddin. (2009). Metode Penelitian Hukum, Jakarta: Sinar Grafika

Djojodirjo, MA. Moegni. (1982). Perbuatan Melawan Hukum, Jakarta: Pradnya Paramita

Fuady, Munir. (2005). Perbuatan Melawan Hukum: Pendekatan Kontemporer. Bandung: PT. Citra Aditya Bakti.

Harjono, Dhaniswara K. (2016). Hukum Properti. Jakarta: Pusat Pengembangan Hukum dan Bisnis Indonesia.

Miru, Ahmad \& Sutarman Yodo. (2015). Hukum Perlindungan Konsumen, Cetakan Kesembilan, Jakarta: RajaGrafindo persada

Murhaini, Suriansyah. (2015). Hukum Rumah Susun. Bandung: Laksbang Grafika

Rosmidi, Mimi dan Imam Koeswahyono. (2010). Konsepsi Hak Milik atas Satuan Rumah Susun dalam Hukum Agraria. Malang: Setara Press

Santoso, Urip. (2010). Pendaftaran Tanah dan Peralihan Hak atas Tanah, Jakarta: Kencana (2017). Hak Atas Tanah, Hak Pengelolaan\&Hak Milik Atas Satuan Rumah Susun, Cetakan Kesatu, Jakarta: Kencana 
Satrio J, (1993). Hukum Perikatan: Perikatan yang Lahir dari Undang-undang, Bandung: PT Citra Aditya Bakti

Simanjuntak, P.N.H., (2016). Hukum Perdata Indonesia, Cetakan Ke-2, (Jakarta: Prenadamedia Group.

Sutedi, Adrian. (2010). Hukum Rumah Susun \& Apartemen. Jakarta: Sinar Grafika

Yosua, Suhanan. (2010). Hak Atas Tanah Timbul (Aanslibbing) Dalam Sistem Hukum Pertanahan Nasional. Jakarta : Restu Agung

\section{Karya Ilmiah:}

Murni, Christiana Sri. (2018). Peralihan Hak Atas Tanah Tanpa Sertipikat. Lex Librum: Jurnal Ilmu Hukum, Volume 4, Nomor 2.

Fauzi, Galih Husain., Ermanto Fahamsyah. (2018). Perlindungan Terhadap Konsumen Yang Tidak Mendapatkan Sertipikat Hak Milik Satuan Rumah Susun. Jurnal Hukum Adigama: Volume 1, Nomor 2. doi: http://dx.doi.org/10.24912/adigama.v1i2.2845

Hartanto, J. Andy. (2013). Kepemilikan Hak Milik Atas Satuan Rumah Susun. Jurnal Rechtens, Volume 2, Nomor 1.

Ara Denara, Made., I Made Dedy Priyanto. (2019). Perjanjian Pengikatan Jual Beli (PPJB) Dalam Transaksi Peralihan Hak Atas Tanah dan/atau Bangunan. Kertha Semaya, Volume 8 Nomor 1.

Oktavia, Mulyani. (2018). Analisis Yuridis Perlindungan Konsumen Atas Kepemilikan Satuan Rumah Susun Yang Berdasarkan Akta Perjanjian Pengikatan Jual Beli (PPJB) Yang Dibangun Diatas Tanah Hak Pengelolaan (Studi Kasus Apartemen Green Pramuka City). Bekasi: Universitas Presiden.

Sarri, Putri N. (2016). Hak Kepemilikan Atas Satuan Rumah Susun Yang Berstatus Hak Guna Bangunan Diatas Hak Pengelolaan (Studi Kasus Putusan No.205/Pdt.G/2007/PN.JKT.PST). Jakarta: Universitas Esa Unggul.

Pongantung, Rio Y. (2018). Perjanjian Pengikatan Jual Beli Oleh Para Pihak Menurut UndangUndang Nomor 20 Tahun 2011 Tentang Rumah Susun. Lex Privatum Volume VI, Nomor 10.

Intan, Siti Nurul., Wardani Rizkianti, (2020). Jual Beli Apartemen Kepada Pihak Ketiga Atas Dasar Perjanjian Pengikatan Jual Beli (PPJB). Adil: Jurnal Hukum, Volume 11, Nomor 1. doi: https://doi.org/10.33476/ajl.v11i1.1445

Slamet, Sri Redjeki. (2013). Tuntutan Ganti Rugi Dalam Perbuatan Melawan Hukum: Suatu Perbandingan Dengan Wanprestasi. Lex Jurnalica Volume 10 Nomor 2.

\section{Sumber Lainnya:}

Habibul Umam Taqiuddin, "Perbuatan Melawan Hukum Dalam Perspektif Hukum Perdata" http://indonesiasociety.lawyer/perbuatan-melawan-hukum-dalam-perspektif-hukumperdata/, diakses tanggal 2 November 2020, Pukul 15.30 WIB

Lita Lia "Bolehkah Jual Apartemen dengan Dasar PPJB Apartemen Bukan AJB?" https://blog.spacestock.com/ppjb-apartemen/, diakses 07 November 2020, Pukul 19.56 WIB 